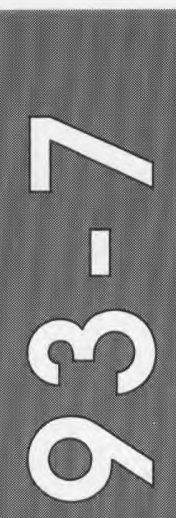

\title{
A Dynamic Study of
} Common Well Screen Materials

Alan D. Hewitt July 1993

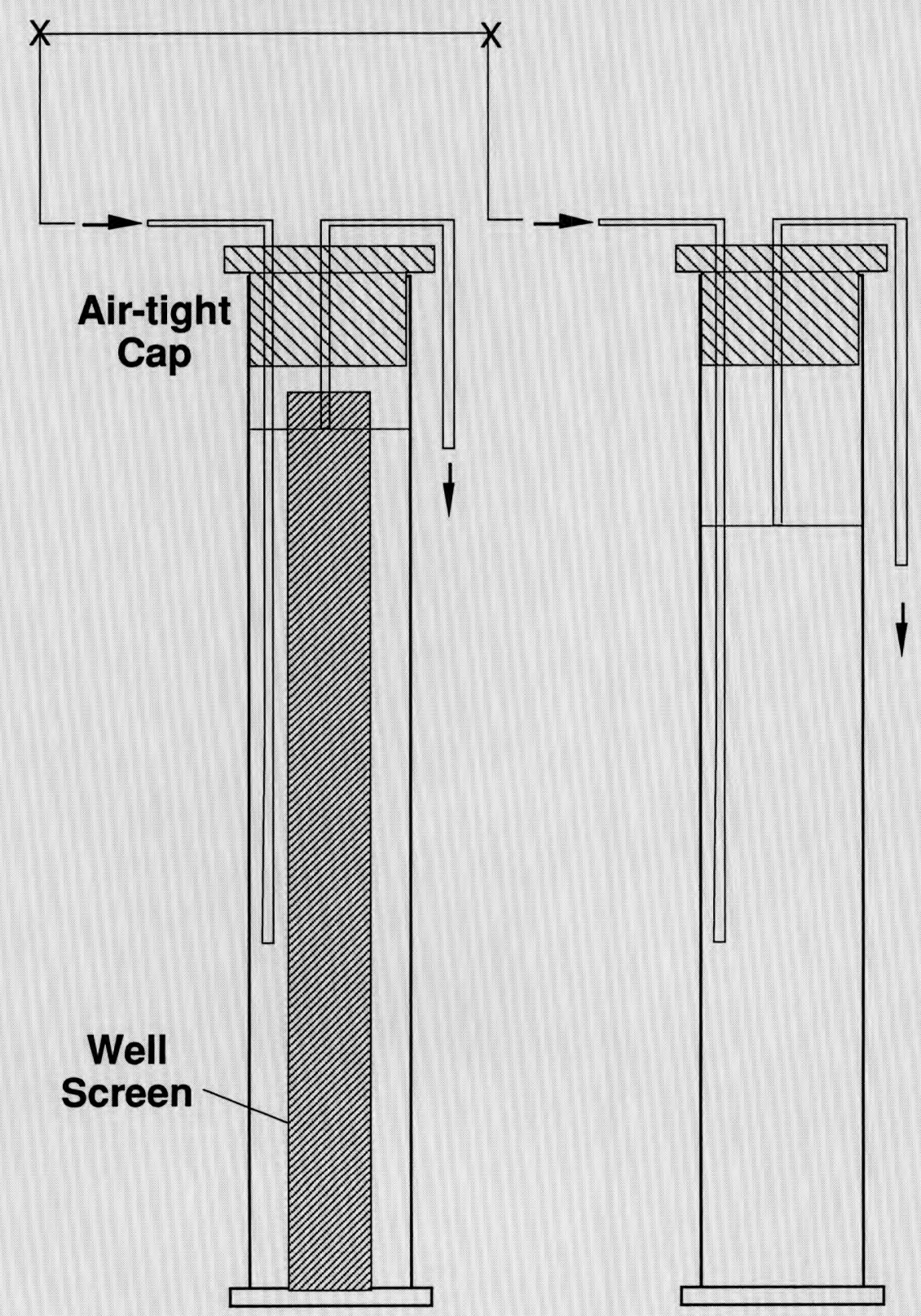




\begin{abstract}
This report describes a dynamic study of the effects of well screen materials on the chemistry of groundwater during contact periods that are consistent with compliance sampling. Tests were done by passing TCE-contaminated aquifer water through monitoring well screens held in a special chamber, without significant changes in major water quality parameters. The results indicate that polymeric materials (i.e., rigid polyvinyl chloride and polytetrafluoroethylene) do not influence aqueous metal and TCE concentrations, while stainless steel casings significantly influence aqueous concentrations of $\mathrm{Cr}, \mathrm{Ni}$ and $\mathrm{Fe}$, especially after developing surface corrosions.
\end{abstract}

Cover: Two chambers of the flow-through apparatus.

For conversion of SI metric units to U.S./British customary units of measurement consult Standard Practice for Use of the International System of Units (SI), ASTM Standard E380-89a, published by the American Society for Testing and Materials, 1916 Race St., Philadelphia, Pa. 19103. 


\section{CRREL Report 93-7}

\section{A Dynamic Study of Common Well Screen Materials}

Alan D. Hewitt

July 1993 


\section{PREFACE}

This report was prepared by Alan D. Hewitt, Research Physical Scientist, Geological Sciences Branch, Research Division, U.S. Army Cold Regions Research and Engineering Laboratory. Funding for this work was provided by the U.S. Army Environmental Center (formerly the U.S. Army Toxic and Hazardous Materials Agency), Martin Stutz, Project Monitor. The authors thank Dr. C.L. Grant and Louise V. Parker for critical review of the text.

This publication reflects the views of the author and does not suggest or reflect policy, practices, programs or doctrine of the U.S. Army or of the Government of the United States. The contents of this report are not to be used for advertising or promotional purposes. Citation of brand names does not constitute an official endorsement or approval of the use of such commercial products. 


\section{CONTENTS}

Preface fntroduction

\section{ILLUSTRATIONS}

\section{Figure}

1. Flow-through chamber apparatus ..................................................................... 2

2. Total Fe concentration in groundwater as a function of residence time ............. 9

\section{TABLES}

Table

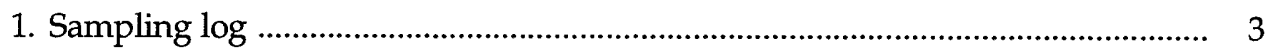

2. Method detection limits established for this study and the National Interim Primary Drinking Water Regulation Levels .................................................... 4

3. Groundwater parameters measured during sampling ….................................... 5

4. Summary of statistical analyses for average analyte concentrations during residence time study..

5. Summary of statistical analyses for average analyte concentrations during flushing study of corroded stainless steel screens .. 


\title{
A Dynamic Study of Common Well Screen Materials
}

\author{
ALAN D. HEWITT
}

\section{INTRODUCTION}

Laboratory studies have shown that the most common well casing materials, rigid polyvinyl chloride (PVC), polytetrafluoroethylene (PTFE), stainless steel 304 (SS 304), and stainless steel 316 (SS 316), can potentially influence, to varying degrees, the chemical composition of groundwater during various static contact periods. Of particular concern for groundwater monitoring are the leaching and sorption of several metals by stainless steel casings (Hewitt 1989a,b, 1992) and sorption of halogenated organic compounds by PTFE and PVC (Reynolds and Gillham 1986, Gillham and O'Hannesin 1988, Parker et al. 1990, Reynolds et al. 1990). Laboratory experiments are a logical first step in material testing, because experimental parameters can be costeffectively managed. However, the inability of laboratory experiments to simulate environmental conditions may limit their results to only identifying potential problems. Conversely, tests done using full-scale field designs are costly and often are unable to detect small changes. Additionally, the interpretation of field studies is often subjective, i.e., it often isn't clear whether spatial or material variables are responsible for observed changes (Houghton and Berger 1984, Barcelona and Helfrich 1986).

In normal use, screened sections of groundwater monitoring wells are positioned in saturated soils where the interstitial waters exhibit a linear velocity. Moreover, the field sampling protocols currently followed require wells to be purged by the removal of successive well volumes of water, usually five, before sampling. Under these circumstances, the water within the screened void of a well that is removed as a representative sample of the surrounding groundwater is a product of these two dynamic flow processes. For this reason the residence time of the water sampled from the well void typically ranges from less than hour to several hours, unless the surrounding substrate exhibits poor transmissivity. Changes in the in-situ chemistry are also of concern, since groundwater is prone to several complex transformations soon after being transferred to the surface, owing to redox shifts and oxygenation. Both concerns about the period that groundwater is exposed to well casing materials and about the in-situ chemistry of groundwater have been valid criticisms of laboratory studies (Nielsen 1988).

In this study we attempt to simulate the characteristic exposure periods for groundwater sampled from a monitoring well, while maintaining the insitu solution chemistry. The water source was drawn

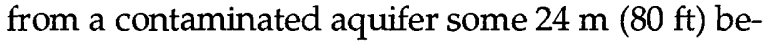
low the surface. The experimental design uses replicate samples, while eliminating variables (i.e., well construction, analyte spatial variability, sampling procedures, etc.) that might confound the testing of well screen materials. We achieved this by individually housing each of the common casing materials to be tested in separate chambers, through which a regulated flow of contaminated groundwater was passed. In all, a series of five test chambers made up the flow system, four containing a section of either PVC, PTFE, SS 304 or SS 316 well screen and the fifth chamber, having no screen, being the control (Fig. 1).

The groundwater that passed simultaneously 


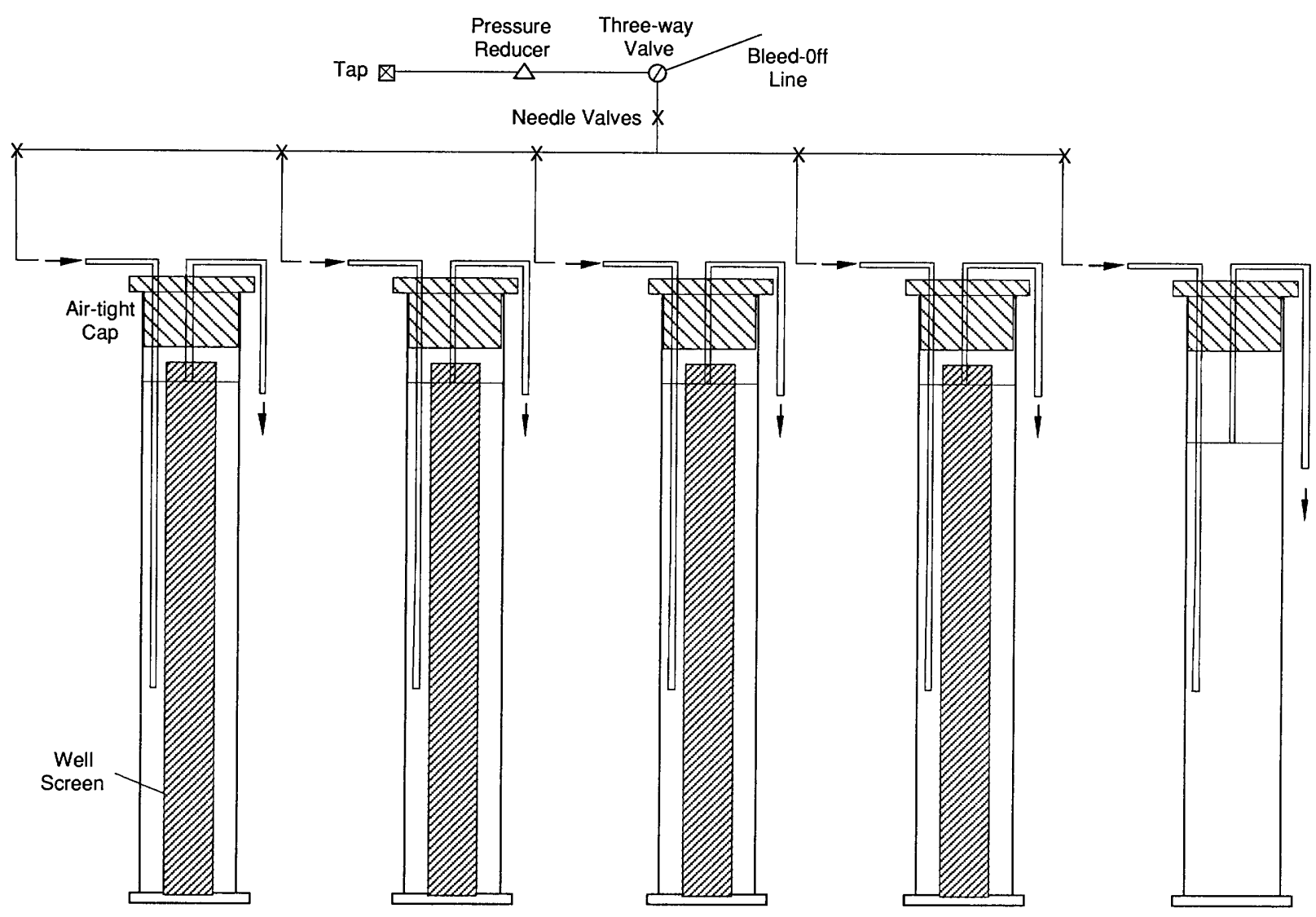

Figure 1. Flow-through chamber apparatus.

through the chambers was taken from a production well drawing water from an aquifer contaminated with trichloroethylene (TCE) and containing moderate concentrations ( $200 \mathrm{mg} \mathrm{Fe} / \mathrm{L}$ ) of total iron. These constituents are easily lost from solution when care is not taken to limit casual atmospheric exposure. By positioning the flow chamber next to the well head and drawing ground water from the well main, this transfer was made without atmospheric exposure.

Dynamic tests were conducted using two different formats. Initially, virgin casing materials were subjected to a range of groundwater flow rates. Between tests the well casings were allowed to age by sitting for an extended period exposed to stagnant groundwater. The second experiment was conducted after we observed surface oxidation on the two stainless steel well screens, and samples were taken periodically as groundwater passed through the system at a constant rate of flow. The first test will provide insight into whether or not material effects exist under dynamic conditions, while the second test assesses the extent that oxidation of the surface of stainless steel screens influences the solution chemistry.

\section{MATERIALS AND METHODS}

For use in the exposure chambers, $61-\mathrm{cm}(2-\mathrm{ft})$ sections of 5-cm (2-in.) o.d. well screens of PVC, PTFE, SS 316 and SS 304 were cut to 44-cm (20-in.) lengths. The PVC, SS 316 and SS 304 casings were bought from Johnson Filtration Systems, Inc., and PTFE from Tomco Mfg., Inc. The two polymeric casings were slotted screens, composed of three or four columns with short (about $4 \mathrm{~cm}$ ) horizontal slits down the side. The stainless steel casings were a wire-wrapped screen. The wound strand of stainless steel was either welded or press fitted, or both, to 20 or more vertical posts. The slits were $0.025 \mathrm{~cm}$ (0.010 in.) for the stainless steel and PVC screens, and about $0.046 \mathrm{~cm}(0.018 \mathrm{in}$.) for the PTFE. The surface of the slotted cuts in the PVC and PTFE screens appeared rough when compared with the external wall surfaces. Both stainless screens had smooth surfaces (possibly passivated) with no visible discoloration (i.e., oxidation) other than the large welds necessary to attach threaded or capped end couplings.

The dynamic flow chambers were made by capping 2-L graduated glass cylinders (Fig. 1), which are commercially available (Thomas Scientific), hav- 
ing internal dimensions of 3.9- $\mathrm{cm}$ (1.5-in.) radius and $50-\mathrm{cm}$ (20-in.) cavity height. Airtight chamber caps of Plexiglas, with rubber O-ring gaskets, filled each cylinder's opening. Each chamber cap had two holes for glass tubing to pass through. The inlet tube was positioned near the edge of the cap and extended $30 \mathrm{~cm}$ down along the inner wall. The outlet tube was positioned in the center of the cap and extended $3 \mathrm{~cm}$ into the cavity of chambers with well screen sections and $8 \mathrm{~cm}$ into the control chamber. The different lengths of the outlet tubes maintained a constant water volume of approximately $1750 \mathrm{~mL}$ in each chamber. During operation, water entered the chamber $27 \mathrm{~cm}$ (22 cm for the control) below the outlet point, exterior of the well casing, and exited from the interior, $1.7 \mathrm{~cm}$ below the screen's top edge. A permanent air pocket stopped the water from contacting the Plexiglas cap, rubber O-rings and freshly cut surface of the well screen. Roughly, the solution volume to casing volume in the flow-through chamber was $4.4 \mathrm{~cm}^{3} / \mathrm{cm}^{3}$.

Water flow to the chambers was regulated by a PVC line pressure reducer and a series of needle valves. Tygon, polypropylene and Teflon tubing and three-way connectors channeled the well water to needle valves positioned at the head of each of the five chambers (Fig. 1). Between each chamber's needle valve and the sample collection point, glass tubing connected by short sections of Tygon tubing, and the glass walls of the graduated cylinder, were the only materials other than the well screens that contacted the groundwater. All of the well screens, connecting tubing and chamber parts were rinsed with deionized type 1 water (Millipore Corp.) and air dried in a class 100 cleanroom prior to use.

Well water was supplied from a production well on site. The aquifer from which this water is drawn was recently found to be contaminated with TCE at a level that ranges from $0.5-2 \mathrm{mg} / \mathrm{L}$. Water was tapped off the well main, which flowed at a constant rate of $1900 \mathrm{~L} / \mathrm{min}$, through a common water spigot. The combination of the water spigot and the PVC pressure reducer were set to allow a constant flow of approximately $600 \mathrm{~mL} / \mathrm{min}$ from the water main. Between the PVC pressure reducer and a needle valve for the entire chamber system, a three-way valve was positioned (Fig. 1) to allow excess water to be sampled from the well head before it reached the chamber system.

\section{TEST DESIGN AND SETUP}

Samples were taken after five chamber volumes of groundwater passed through the system, at a set
Table 1. Sampling log.

\begin{tabular}{|c|c|c|}
\hline & $\begin{array}{l}\text { Residence time } \\
\text { (hours) }\end{array}$ & $\begin{array}{c}\text { Flow rate/chamber } \\
(\mathrm{mL} / \mathrm{min})\end{array}$ \\
\hline \multicolumn{3}{|c|}{ Residence time study } \\
\hline \multicolumn{3}{|c|}{ Day 1 (3 Aug 92) } \\
\hline 1st Event * & 0.25 & 113 \\
\hline 2nd Event & 0.50 & 56 \\
\hline 3rd Event & 1.0 & 28 \\
\hline \multicolumn{3}{|c|}{ Day 2 (4 Aug 92) } \\
\hline 4th Event ${ }^{\dagger}$ & 2.0 & 14 \\
\hline \multicolumn{3}{|c|}{ Day 3 (5 Aug 92) } \\
\hline 5th Event ${ }^{+}$ & 4.0 & \\
\hline \multicolumn{3}{|c|}{ Day 4 (6 Aug 92) } \\
\hline 6th Event ${ }^{\dagger}$ & 8.0 & 3.5 \\
\hline \multirow{2}{*}{\multicolumn{3}{|c|}{$\begin{array}{l}\text { Chamber flushing study of } \\
\text { corroded stainless steel screens } \\
\text { Day } 5 \text { ( } 23 \text { Oct } 92 \text { ) }\end{array}$}} \\
\hline & & Day 5 (23 Oct 92) \\
\hline 7th Event ${ }^{* *}$ & 0.50 & 56 \\
\hline 8th Event & 0.50 & 56 \\
\hline 9th Event & 0.50 & 56 \\
\hline \multicolumn{3}{|c|}{$\begin{array}{l}\text { * Water quality samples taken after sampling } \\
\text { round. } \\
\text { + Water quality samples taken prior to sampling } \\
\text { round. } \\
\text { * Sampling rounds taken after } 5,10 \text {, and } 15 \text { cham- } \\
\text { ber volume flushes. Water quality samples taken } \\
\text { just prior to sampling round. }\end{array}$} \\
\hline
\end{tabular}

rate of flow. This sample sequence simulates the length of time that groundwater is exposed to well casing materials, as would be established by the transmissivity of the aquifer being sampled, after the well has been purged by the removal of five well volumes.

For the tests on virgin well screen (i.e., no visible rust), flow rates were set to create residence times (i.e., chamber exchange rates) of $0.25,0.5,1,2,4$ and 8 hours (Table 1). The residence times (i.e., flow) were controlled in a sequence from short (fast) to longer (slower). However, the system failed to maintain a constant and equal flow rate through all of the chambers when unattended (over night); thus, continuous flow was interrupted for the three slowest rates (residence times of 2, 4 and 8 hours). For the 2-hour residence time test, the proper flow was reestablished early in the morning and samples were collected 10 hours later. For the two longest residence times, flow was increased early in the morning allowing four volume exchanges to pass, then the proper rate was set for the final volume flush before sampling. Table 1 shows the sampling schedule for both the analytes of interest and the water quality parameters.

The experiment designed to detect chemical solution alterations caused by the development of visible surface oxidation on the stainless steel well 
screens had a single flow rate (Table 1). Surface oxidation developed on the stainless screens when they were subjected to stagnant groundwater over a 75day period. Samples were collected after 5, 10 and 15 chamber volumes had been exchanged.

A third study was conducted but is not included in the main body of this report. It is, however, included as Appendix A. In it, well water was spiked with metals to see if they were affected by the oxidation sites on the stainless steel.

For the residence time study using the virgin casings, samples were collected for the analysis of both TCE and metals. However, only samples for the analysis of metals were collected for the study made after the development of visible corrosion on the stainless casings. During a sampling event, triplicate samples for TCE and metals analysis were collected from the chamber outlets, along with a single sample (TCE/metals) from the bleed-off line. Water quality samples for conductivity and $\mathrm{pH}$ were taken just prior to a sampling event, with the exception of day one of the experiment using virgin casings. Here, only a single round of water quality samples was taken after the first sampling event. For the study done after the development of surface oxidation, dissolved oxygen measurements were made along with conductivity and $\mathrm{pH}$ measurements.

Groundwater samples taken for the analysis of TCE were obtained in either 40 - or $3.5-\mathrm{mL}$ Volatile Organic Analysis (VOA) vials, with open, Teflonfaced silicon rubber septa. The large VOA vials were used for the three fastest flow rates, and the small ones for the three slower rates of flow. All VOA vials were positioned so that the end of the outlet tube extended to the bottom of the vial, thus allowing the groundwater $t c$ be transferred without agitation and with minimal surface area exposure. Vials were filled until overflowing and the caps were also filled, making it easier to avoid trapping air bubbles during capping. Samples taken for metal analysis were obtained by collecting water droplets breaking off the end of the discharge tube. Approximately 8-mL volumes were collected in small, clean polyethylene bottles $(10.5 \mathrm{~mL})$, and were acidified below $\mathrm{pH} 2$ by adding $0.25 \mathrm{~mL}$ of concentrated $\mathrm{HNO}_{3}$ (G. Frederick Smith, redistilled).

\section{ANALYSIS}

Cadmium $(\mathrm{Cd})$, copper $(\mathrm{Cu})$, chromium $(\mathrm{Cr})$, iron $(\mathrm{Fe})$, nickel $(\mathrm{Ni})$ and lead $(\mathrm{Pb})$ were analyzed by Graphite Furnace Atomic Absorption (GFAA), using a Perkin-Elmer model 5100PC Zeeman background-corrected Atomic Absorption Spectropho- tometer, following the general guidelines provided by the manufacturer. These metals were selected for analysis on the basis of results of previous static laboratory studies with the same materials (Hewitt 1989a,b, 1992).

TCE was determined by HeadSpace Gas Chromatography (HS/GC) at room temperature, and concentrations were established by comparison to aqueous standards (Dietz and Singley 1979, Hewitt et al. 1991). The gas chromatograph used was a Photovac Model $10 S 10$ (Photovac, Inc.), equipped with a 30-cm length, 10\% SE-30 on chromosorb 80/100 mesh, packed column. Aqueous samples were prepared for analysis by puncturing the septa with two hypodermic needles and removing one quarter of the VOA solution with a Luer Lok syringe while allowing air from the room to fill the void created. Headspace equilibrium was facilitated by 2 minutes of vigorous hand shaking.

The analyses' sensitivity was appropriate for the existing levels of Fe and TCE, or set so that either Method Detection Limit (MDL, Federal Register 1984) of less than $1 \mu \mathrm{g} / \mathrm{L}$, or less than $1 \%$ of the current National Interim Primary Drinking Water Regulations (NIPDWR, Federal Register 1975), was achieved. If analyte concentration in at least one of the chambers was greater than the MDL established for this study (Table 2), the results were analyzed statistically. To see if the different screen materials influenced the analytes of interest as the groundwater flowed through the chamber system, an analysis of variance (ANOVA) and least-significant-difference (LSD) analysis were applied at the $95 \%$ confidence level. Estimated values below the MDLs were used in this statistical analysis so as not to skew the variances. LSD analyses that fail to distinguish differences in concentration for material influences greater than that of the appropriate MDL were not considered significant.

Table 2. Method detection limits (MDL) established for this study and the National Interim Primary Drinking Water Regulation Levels (Federal Register 1975).

\begin{tabular}{lcc} 
Analyte & $\begin{array}{c}M D L \\
(\mu \mathrm{g} / \mathrm{L})\end{array}$ & $\begin{array}{c}\text { NIPDWR levels } \\
(\mu \mathrm{g} / \mathrm{L})\end{array}$ \\
\hline $\mathrm{Cd}$ & 0.096 & 10 \\
$\mathrm{Cu}$ & 0.35 & $\mathrm{NA}^{*}$ \\
$\mathrm{Cr}$ & 0.24 & 50 \\
$\mathrm{Fe}$ & 23 & $\mathrm{NA}$ \\
$\mathrm{Ni}$ & 0.95 & $\mathrm{NA}$ \\
$\mathrm{Pb}$ & 0.46 & 50 \\
$\mathrm{TCE}$ & 0.17 & 5 \\
\hline
\end{tabular}

* Not available. 
Conductivity, $\mathrm{pH}$ and dissolved oxygen were measured using a Leeds and Northrup electrolytic conductivity bridge, a semi-micro glass combination $\mathrm{pH}$ electrode (Orion) calibrated with low ionic strength buffers, and a micro-oxygen electrode (Microelectrodes, Inc.) respectively.

\section{RESULTS}

\section{Water quality}

Table 3 lists all of the water quality measurements taken in conjunction with the two studies. Comparison of values within individual sampling events, and over the course of both experiments, shows only minor variations in these parameters.

Table 3. Groundwater parameters measured during sampling.

\begin{tabular}{|c|c|c|c|c|c|c|}
\hline & $\begin{array}{l}\text { Bleed-off } \\
\text { line }\end{array}$ & Control & PTFE & $P V C$ & SS 304 & SS 316 \\
\hline \multicolumn{7}{|c|}{ Residence time study } \\
\hline \multicolumn{7}{|c|}{ Day 1} \\
\hline $\begin{array}{c}\text { Conductance } \\
(\mu \mathrm{mhos})\end{array}$ & \multicolumn{5}{|c|}{ Conductance } & 494 \\
\hline $\mathrm{pH}$ & 7.65 & 7.63 & 7.62 & 7.63 & 7.65 & 7.63 \\
\hline \multicolumn{7}{|l|}{ Day $2^{*}$} \\
\hline $\begin{array}{l}\text { Conductance } \\
\text { ( } \mu \text { mhos })\end{array}$ & 503 & 504 & 514 & 518 & 518 & 518 \\
\hline $\mathrm{pH}$ & 7.85 & 7.77 & 7.80 & 7.80 & 7.81 & 7.76 \\
\hline \multicolumn{7}{|l|}{ Day $3^{+}$} \\
\hline $\begin{array}{c}\text { Conductance } \\
(\mu \mathrm{mhos})\end{array}$ & \multicolumn{5}{|c|}{ Conductance } & 502 \\
\hline $\mathrm{pH}$ & 7.70 & 8.01 & 7.84 & 7.83 & 7.82 & 7.84 \\
\hline \multicolumn{7}{|l|}{ Day $4^{* * *}$} \\
\hline $\begin{array}{l}\text { Conductance } \\
(\mu \mathrm{mhos}) \\
\mathrm{pH}\end{array}$ & $\begin{array}{l}488 \\
7.71\end{array}$ & $\begin{array}{l}488 \\
7.84\end{array}$ & $\begin{array}{l}488 \\
7.85\end{array}$ & $\begin{array}{l}498 \\
7.83\end{array}$ & $\begin{array}{l}500 \\
7.91\end{array}$ & $\begin{array}{l}502 \\
7.79\end{array}$ \\
\hline \multicolumn{7}{|c|}{ Chamber flushing study of corroded stainless screens } \\
\hline $\begin{array}{l}\text { Conductance } \\
(\mu \mathrm{mhos}) \\
\mathrm{pH}\end{array}$ & $\begin{array}{l}458 \\
7.71 \\
<0.5\end{array}$ & $\begin{array}{l}458 \\
7.84 \\
<0.5\end{array}$ & $\begin{array}{l}456 \\
7.85 \\
<0.5\end{array}$ & $\begin{array}{l}456 \\
7.83 \\
<0.5\end{array}$ & $\begin{array}{l}448 \\
7.91 \\
<0.5\end{array}$ & $\begin{array}{l}458 \\
7.79 \\
<0.5\end{array}$ \\
\hline \multicolumn{7}{|l|}{ Ten Flushes } \\
\hline \multicolumn{6}{|l|}{ Conductance } & 471 \\
\hline $\mathrm{pH}$ & 7.71 & 7.84 & 7.85 & 7.83 & 7.91 & 7.79 \\
\hline $\mathrm{DO}(\mathrm{mg} / \mathrm{L})$ & $<0.5$ & $<0.5$ & $<0.5$ & $<0.5$ & $<0.5$ & $<0.5$ \\
\hline \multicolumn{7}{|l|}{ Fifteen Flushes } \\
\hline \multicolumn{7}{|l|}{ Conductance } \\
\hline $\mathrm{pH}$ & 7.64 & 7.66 & 7.70 & 7.68 & 7.66 & 7.68 \\
\hline $\mathrm{DO}(\mathrm{mg} / \mathrm{L})$ & $<0.5$ & $<0.5$ & $<0.5$ & $<0.5$ & $<0.5$ & $<0.5$ \\
\hline
\end{tabular}

* Between day 1 and day 2, the system failed to maintain flow in control, PTFE and SS 316 chambers.

+ Between day 2 and day 3 , the system failed to maintain flow in control and PVC chambers.

*** Between day 3 and day 4 , the system flow stopped in all chambers.
In addition, the comparison of the quality of water before it entered the system (at the bleed-off line) with that which passed through the chambers failed to show any apparent effects attributable to either the individual screen materials or the experimental apparatus.

\section{Residence time experiment}

Table 4 shows the mean concentrations and the statistical analysis of the results obtained for $\mathrm{Cr}, \mathrm{Cu}$, $\mathrm{Fe}, \mathrm{Ni}$ and TCE in the groundwater samples. Both $\mathrm{Cd}$ and $\mathrm{Pb}$ were consistently found at concentrations below their respective MDLs, and thus were not subjected to statistical interpretation. No significant material effects were found for the TCE concentrations in the groundwater samples. Of the metals found in concentrations above their MDLs, only $\mathrm{Cr}$ is regulated by the NIPDWR. The results showed that $\mathrm{Cr}$ was consistently released from the SS 304 well screen during the three shortest residence time experiments, but only the first sampling round showed significant differences from the concentrations obtained for the other chambers. Similarly, $\mathrm{Cu}$ and $\mathrm{Ni}$ leached into groundwater exposed to SS 304 and SS 316 . Here the SS 304 continued to show significant contributions tu solution for both of these metals, independent of residence time. Contrary to the results showing that metals were leached into the groundwater, total Fe concentrations generally decreased for all of the casing materials as compared to the control with increasing residence time (Fig. 2). The loss of total Fe was most pronounced for SS 316 , as compared to the polymeric materials and the control, for residence times of 0.5 hours and longer. The pattern of significant material influences on solution concentrations of total Fe was SS 316 > SS 304 $>$ PVC and PTFE $>$ control for the two longest residence time tests.

\section{Flushing experiment with oxidized well screens}

Table 5 shows the statistical analysis of results obtained for $\mathrm{Cr}$, Fe and $\mathrm{Ni}$ in groundwater samples. For this experiment, $\mathrm{Cu}$ as well as $\mathrm{Cd}$ and $\mathrm{Pb}$ failed to be detected above their respective MDLs. With a pattern that was generally similar to the previous test, both SS 316 and SS 304 were found to leach Cr and $\mathrm{Ni}$ and sorb $\mathrm{Fe}$ in statistically significant amounts when compared to the polymeric materials and the control. Here, the significant influences persisted even after 15 chamber flushes. Statistical analysis showed that SS 304 was the worst well screen material for leaching both $\mathrm{Cr}$ and $\mathrm{Ni}$, while SS 316 generally showed the greatest sorption in total Fe. 
Table 4. Summary of statistical analyses for average analyte concentrations $(\mu \mathrm{g} / \mathrm{L})$ during residence time study. Materials with common underlining are not different at the $95 \%$ confidence level as determined by the least signiflcant difference (LSD) test.

\begin{tabular}{|c|c|c|c|c|c|c|}
\hline \multicolumn{3}{|c|}{$\begin{array}{c}\text { Residence } \\
\text { time } \\
\text { (hr) }\end{array}$} & \multicolumn{4}{|c|}{ Well casing } \\
\hline \multicolumn{7}{|c|}{ Chromium (in bleed-off line, $n=6,0.16^{*} 0.10^{\dagger}$ ) } \\
\hline$(\mathrm{LSD}=0.21)$ & 0.25 & $\begin{array}{c}\text { PVC } \\
0.10 \\
(0.00)\end{array}$ & $\begin{array}{c}\text { PTFE } \\
0.13 \\
(0.06)\end{array}$ & $\begin{array}{c}\text { SS } 316 \\
0.20 \\
(0.00)\end{array}$ & $\begin{array}{c}\text { Control } \\
0.27 \\
(0.12)\end{array}$ & $\begin{array}{r}\text { SS } 304 \\
0.57^{*} \\
(0.12)^{+}\end{array}$ \\
\hline$(\mathrm{LSD}=0.48)$ & 0.50 & $\begin{array}{c}\text { PVC } \\
0.10 \\
(0.00)\end{array}$ & $\begin{array}{c}\text { Control } \\
0.20 \\
(0.17)\end{array}$ & $\begin{array}{c}\text { PTFE } \\
0.23 \\
(0.06)\end{array}$ & $\begin{array}{c}\text { SS } 316 \\
0.27 \\
(0.06)\end{array}$ & $\begin{array}{r}\text { SS } 304 \\
0.63 \\
(0.35)\end{array}$ \\
\hline$(\mathrm{LSD}=1.89)$ & 1.0 & $\begin{array}{c}\text { PVC } \\
0.10 \\
(0.00)\end{array}$ & $\begin{array}{c}\text { Control } \\
0.17 \\
(0.06)\end{array}$ & $\begin{array}{c}\text { PTFE } \\
0.17 \\
(0.06)\end{array}$ & $\begin{array}{c}\text { SS } 304 \\
0.43 \\
(0.15)\end{array}$ & $\begin{array}{r}\text { SS } 316 \\
1.20 \\
(1.56)\end{array}$ \\
\hline$(\mathrm{LSD}=0.38)$ & 2.0 & $\begin{array}{c}\text { PTFE } \\
0.13 \\
(0.06)\end{array}$ & $\begin{array}{c}\text { Control } \\
0.23 \\
(0.12)\end{array}$ & $\begin{array}{c}\text { PVC } \\
0.27 \\
(0.21) \\
\end{array}$ & $\begin{array}{c}\text { SS } 316 \\
0.30 \\
(0.17)\end{array}$ & $\begin{array}{r}\text { SS } 304 \\
0.40 \\
(0.10) \\
\end{array}$ \\
\hline$(\mathrm{LSD}=0.84)$ & 4.0 & $\begin{array}{c}\text { SS } 316 \\
0.23 \\
(0.23)\end{array}$ & $\begin{array}{c}\text { PVC } \\
0.27 \\
(0.27)\end{array}$ & $\begin{array}{c}\text { Control } \\
0.37 \\
(0.32) \\
\end{array}$ & $\begin{array}{c}\text { SS } 304 \\
0.40 \\
(0.36) \\
\end{array}$ & $\begin{array}{r}\text { PTFE } \\
0.47 \\
(0.38) \\
\end{array}$ \\
\hline$(\mathrm{LSD}=0.20)$ & 8.0 & $\begin{array}{c}\text { Control } \\
0.13 \\
(0.06)\end{array}$ & $\begin{array}{c}\text { PVC } \\
0.20 \\
(0.10)\end{array}$ & $\begin{array}{c}\text { SS } 316 \\
0.20 \\
(0.00)\end{array}$ & $\begin{array}{c}\text { SS } 304 \\
0.23 \\
(0.06)\end{array}$ & $\begin{array}{r}\text { PTFE } \\
0.30 \\
(0.10)\end{array}$ \\
\hline
\end{tabular}

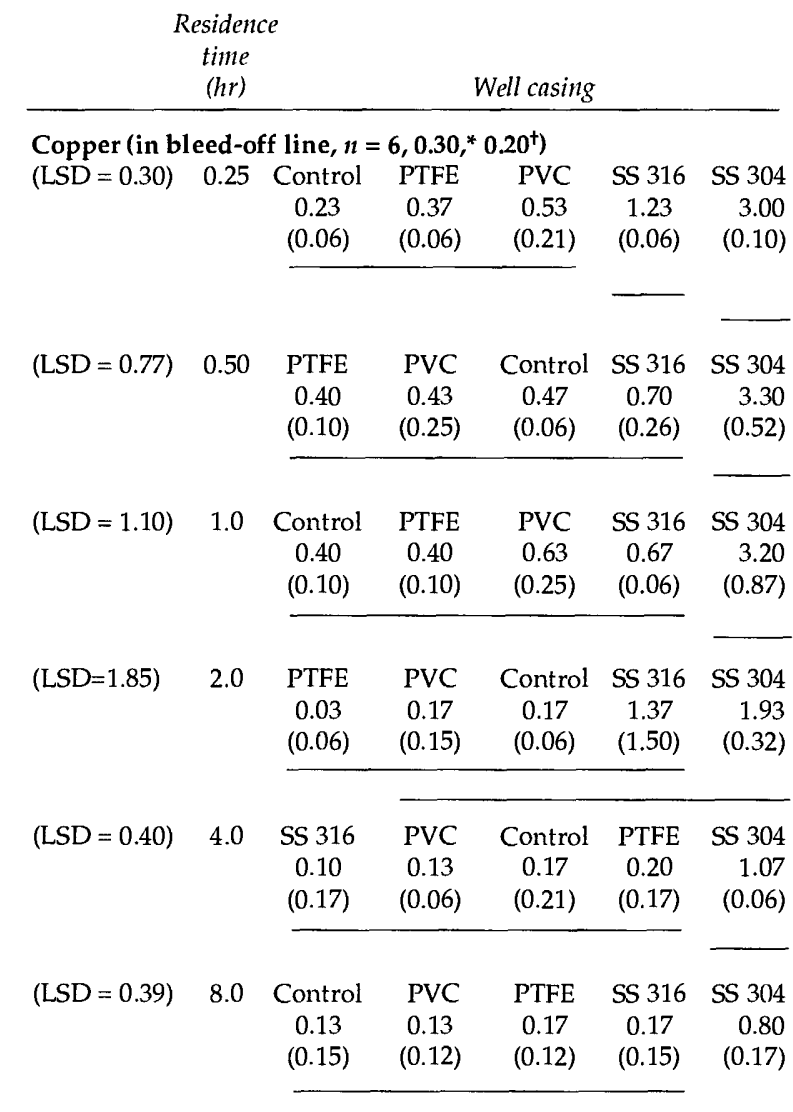

\begin{tabular}{|c|c|c|c|c|c|c|}
\hline & $\begin{array}{c}\text { Resideno } \\
\text { time } \\
(\mathrm{hr})\end{array}$ & & & ell casin & & \\
\hline \multicolumn{4}{|c|}{ Iron (in bleed-off line, $n=6,215, * 24^{+}$) } & & & \\
\hline$(\mathrm{LSD}=43)$ & 0.25 & $\begin{array}{c}\text { SS } 304 \\
223 \\
(7.6)\end{array}$ & $\begin{array}{c}\text { SS } 316 \\
231 \\
(20)\end{array}$ & $\begin{array}{l}\text { PVC } \\
243 \\
(18)\end{array}$ & $\begin{array}{c}\text { Control } \\
243 \\
(3.6)\end{array}$ & $\begin{array}{cc}1 & \text { PTFE } \\
248 \\
(22)\end{array}$ \\
\hline$(\mathrm{LSD}=13)$ & 0.50 & $\begin{array}{c}\text { SS } 304 \\
184 \\
(0.0)\end{array}$ & $\begin{array}{c}\text { SS } 316 \\
199 \\
(7.1)\end{array}$ & $\begin{array}{c}\text { PVC } \\
220 \\
(1.7)\end{array}$ & $\begin{array}{c}\text { PTFE } \\
222 \\
(5.1)\end{array}$ & $\begin{array}{r}\text { Control } \\
225 \\
(6.1)\end{array}$ \\
\hline$(\mathrm{LSD}=24)$ & 1.0 & $\begin{array}{c}\text { SS } 316 \\
170 \\
(6.5)\end{array}$ & $\begin{array}{c}\text { SS } 304 \\
178 \\
(9.7)\end{array}$ & $\begin{array}{c}\text { PVC } \\
195 \\
(14)\end{array}$ & $\begin{array}{c}\text { PTFE } \\
196 \\
(7.5)\end{array}$ & $\begin{array}{c}\text { Control } \\
211 \\
(4.2)\end{array}$ \\
\hline$(\mathrm{LSD}=24)$ & 2.0 & $\begin{array}{c}\text { SS } 316 \\
94 \\
(0.0)\end{array}$ & $\begin{array}{c}\text { PTFE } \\
167 \\
(3.5)\end{array}$ & $\begin{array}{c}\text { PVC } \\
168 \\
(8.5)\end{array}$ & $\begin{array}{c}\text { SS } 304 \\
194 \\
(5.5)\end{array}$ & $\begin{array}{r}\text { Control } \\
200 \\
(7.0)\end{array}$ \\
\hline$(\mathrm{LSD}=15)$ & 4.0 & $\begin{array}{c}\text { SS } 316 \\
87 \\
(2.0)\end{array}$ & $\begin{array}{c}\text { SS } 304 \\
110 \\
(6.2)\end{array}$ & $\begin{array}{c}\text { PTFE } \\
134 \\
(3.0)\end{array}$ & $\begin{array}{c}\text { PVC } \\
145 \\
(5.5)\end{array}$ & $\begin{array}{c}\text { Control } \\
186 \\
(2.6)\end{array}$ \\
\hline$(\mathrm{LSD}=23)$ & 8.0 & $\begin{array}{c}\text { SS } 316 \\
62 \\
(4.7)\end{array}$ & $\begin{array}{c}\text { SS } 304 \\
88 \\
(8.0)\end{array}$ & $\begin{array}{c}\text { PVC } \\
105 \\
(8.0)\end{array}$ & $\begin{array}{c}\text { PTFE } \\
124 \\
(6.8)\end{array}$ & $\begin{array}{r}\text { Control } \\
167 \\
(13.6)\end{array}$ \\
\hline
\end{tabular}

* Average.

+ Standard deviation 
Table 4 (cont'd).

\begin{tabular}{|c|c|c|c|c|c|c|c|c|c|c|c|c|c|}
\hline \multicolumn{3}{|c|}{$\begin{array}{c}\text { Residence } \\
\text { time } \\
(h r)\end{array}$} & \multicolumn{4}{|c|}{ Well casing } & \multicolumn{3}{|c|}{$\begin{array}{c}\text { Residence } \\
\text { time } \\
(l h r)\end{array}$} & \multicolumn{4}{|c|}{ Well casing } \\
\hline Nickel (in ble & ed-off & f line, $n=$ & $6,0.53,{ }^{*}$ & $\left..44^{\dagger}\right)$ & & & \multicolumn{7}{|c|}{ Trichloroethylene (in bleed-off line, $n=6,1.82,{ }^{*} 0.12^{\dagger}$ ) } \\
\hline$(\mathrm{LSD}=1.39)$ & 0.25 & $\begin{array}{c}\text { Control } \\
0.77 \\
(0.49)\end{array}$ & $\begin{array}{c}\text { PVC } \\
0.87 \\
(0.51)\end{array}$ & $\begin{array}{c}\text { PTFE } \\
0.90 \\
(0.90)\end{array}$ & $\begin{array}{c}\text { SS } 316 \\
2.63 \\
(0.57)\end{array}$ & $\begin{array}{c}\text { SS } 304 \\
3.13 \\
(0.51)\end{array}$ & $(\mathrm{LSD}=0.16)$ & 0.25 & $\begin{array}{c}\text { SS 304 } \\
1.75 \\
(0.07)\end{array}$ & $\begin{array}{c}\text { Control } \\
1.78 \\
(0.03)\end{array}$ & $\begin{array}{c}\text { PTFE } \\
1.78 \\
(0.08)\end{array}$ & $\begin{array}{c}\text { SS } 316 \\
1.79 \\
(0.08)\end{array}$ & $\begin{array}{r}\text { PVC } \\
1.80 \\
(0.03)\end{array}$ \\
\hline \multirow[t]{2}{*}{$(\mathrm{LSD}=0.94)$} & 0.50 & $\begin{array}{c}\text { Control } \\
0.47\end{array}$ & $\begin{array}{l}\text { PTFE } \\
0.60\end{array}$ & $\begin{array}{l}\text { PVC } \\
0.63\end{array}$ & $\begin{array}{c}\text { SS } 316 \\
1.43\end{array}$ & $\begin{array}{c}\text { SS } 304 \\
4.30\end{array}$ & $(\mathrm{LSD}=0.29)$ & 0.50 & $\begin{array}{c}\text { SS } 304 \\
1.72 \\
(0.08)\end{array}$ & $\begin{array}{c}\text { SS } 316 \\
1.74 \\
(0.14)\end{array}$ & $\begin{array}{c}\text { PVC } \\
1.74 \\
(0.12)\end{array}$ & $\begin{array}{c}\text { Control } \\
1.79 \\
(0.03)\end{array}$ & $\begin{array}{r}\text { PTFE } \\
1.79 \\
(0.14)\end{array}$ \\
\hline & & & & & & & $(\mathrm{LSD}=0.08)$ & 1.0 & $\begin{array}{c}\text { PVC } \\
1.67 \\
(0.04)\end{array}$ & $\begin{array}{c}\text { SS } 304 \\
1.68 \\
(0.03)\end{array}$ & $\begin{array}{c}\text { Control } \\
1.68 \\
(0.04)\end{array}$ & $\begin{array}{c}\text { SS } 316 \\
1.69 \\
(0.02)\end{array}$ & $\begin{array}{r}\text { PTFE } \\
1.71 \\
(0.01)\end{array}$ \\
\hline$(\mathrm{LSD}=0.51)$ & 1.0 & $\begin{array}{c}\text { PTFE } \\
0.57 \\
(0.35)\end{array}$ & $\begin{array}{c}\text { SS } 316 \\
0.60 \\
(0.10)\end{array}$ & $\begin{array}{c}\text { PVC } \\
0.67 \\
(0.12)\end{array}$ & $\begin{array}{c}\text { Control } \\
0.90 \\
(0.10)\end{array}$ & $\begin{array}{c}\text { SS } 304 \\
5.53 \\
(0.15)\end{array}$ & $(\mathrm{LSD}=0.21)$ & 2.0 & $\begin{array}{c}\text { PTFE } \\
1.93 \\
(0.06)\end{array}$ & $\begin{array}{c}\text { Control } \\
1.95 \\
(0.08)\end{array}$ & $\begin{array}{l}\text { SS } 316 \\
1.96 \\
(0.09)\end{array}$ & $\begin{array}{c}\text { SS } 304 \\
1.99 \\
(0.04)\end{array}$ & $\begin{array}{r}\text { PVC } \\
2.04 \\
(0.05)\end{array}$ \\
\hline$(\mathrm{LSD}=1.49)$ & 2.0 & $\begin{array}{c}\text { PVC } \\
0.70 \\
(0.52)\end{array}$ & $\begin{array}{c}\text { PTFE } \\
0.77 \\
(0.25)\end{array}$ & $\begin{array}{c}\text { Control } \\
0.90 \\
(0.79)\end{array}$ & $\begin{array}{c}\text { SS } 316 \\
0.90 \\
(0.17)\end{array}$ & $\begin{array}{c}\text { SS } 304 \\
33.8 \\
(0.74)\end{array}$ & $(\mathrm{LSD}=0.18)$ & 4.0 & $\begin{array}{c}\text { SS } 316 \\
1.85 \\
(0.07)\end{array}$ & $\begin{array}{c}\text { Control } \\
1.86 \\
(0.08)\end{array}$ & $\begin{array}{c}\text { SS 304 } \\
1.86 \\
(0.09)\end{array}$ & $\begin{array}{c}\text { PTFE } \\
1.87 \\
(0.04)\end{array}$ & $\begin{array}{r}\text { PVC } \\
1.89 \\
(0.05)\end{array}$ \\
\hline$(\mathrm{LSD}=0.95)$ & 4.0 & $\begin{array}{c}\text { PTFE } \\
0.63 \\
(0.06)\end{array}$ & $\begin{array}{c}\text { Control } \\
0.67 \\
(0.31)\end{array}$ & $\begin{array}{c}\text { SS 316 } \\
0.73 \\
(0.40)\end{array}$ & $\begin{array}{c}\text { PVC } \\
0.80 \\
(0.50)\end{array}$ & $\begin{array}{c}\text { SS } 304 \\
11.6 \\
(0.35)\end{array}$ & $(\mathrm{LSD}=0.18)$ & 8.0 & $\begin{array}{c}\text { PTFE } \\
1.81 \\
(0.07) \\
\end{array}$ & $\begin{array}{c}\text { PVC } \\
1.82 \\
(0.10)\end{array}$ & $\begin{array}{c}\text { SS } 316 \\
1.86 \\
(0.04)\end{array}$ & $\begin{array}{c}\text { Control } \\
1.87 \\
(0.07)\end{array}$ & $\begin{array}{r}\text { SS } 304 \\
1.90 \\
(0.05)\end{array}$ \\
\hline$(\mathrm{LSD}=0.92)$ & 8.0 & $\begin{array}{c}\text { Control } \\
0.70 \\
(0.26)\end{array}$ & $\begin{array}{c}\text { SS } 316 \\
0.70 \\
(0.17)\end{array}$ & $\begin{array}{c}\text { PVC } \\
0.93 \\
(0.21)\end{array}$ & $\begin{array}{c}\text { PTFE } \\
1.10 \\
(0.26)\end{array}$ & $\begin{array}{c}\text { SS } 304 \\
9.67 \\
(0.61)\end{array}$ & & & & & & & \\
\hline
\end{tabular}

* Average.

+ Standard deviation. 
Table 5. Summary of statistical analyses for average analyte concentrations $(\mu \mathrm{g} / \mathrm{L})$ during flushing study of corroded stainless steel screens. Materials with common underlining are not different at the $95 \%$ confidence level as determined by the least significant difference (LSD).

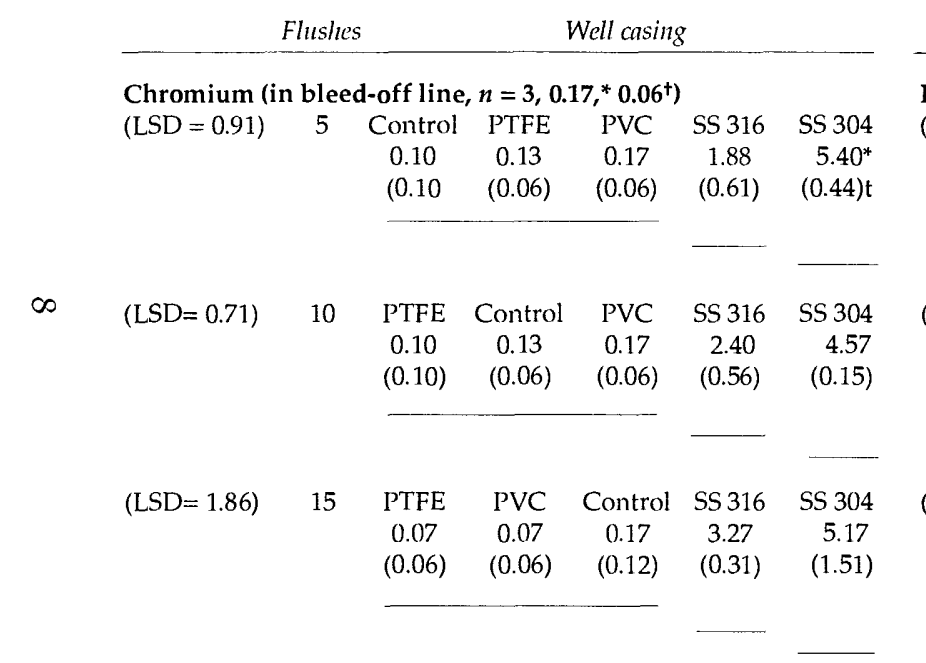

\begin{tabular}{|c|c|c|c|c|c|c|}
\hline \multicolumn{4}{|c|}{ Flushes } & \multicolumn{3}{|c|}{ Well casing } \\
\hline \multicolumn{7}{|c|}{ Iron (in bleed-off line, $n=3,215^{*}, 9.4^{\dagger}$ ) } \\
\hline$(\mathrm{LSD}=20)$ & 5 & $\begin{array}{c}\text { SS } 316 \\
118 \\
(15)\end{array}$ & $\begin{array}{c}\text { SS } 304 \\
146 \\
(3.1)\end{array}$ & $\begin{array}{c}\text { PVC } \\
189 \\
(1.0)\end{array}$ & $\begin{array}{c}\text { PTFE } \\
190 \\
(3.5)\end{array}$ & $\begin{array}{c}\text { Control } \\
196 \\
(6.9)\end{array}$ \\
\hline$(\mathrm{LSD}=16)$ & 10 & $\begin{array}{c}\text { SS } 316 \\
119 \\
(5.5)\end{array}$ & $\begin{array}{c}\text { SS } 304 \\
137 \\
(6.1)\end{array}$ & $\begin{array}{c}\text { PVC } \\
214 \\
(2.1)\end{array}$ & $\begin{array}{c}\text { PTFE } \\
214 \\
(4.5)\end{array}$ & $\begin{array}{c}\text { Control } \\
217 \\
(9.5)\end{array}$ \\
\hline$(\mathrm{LSD}=22)$ & 15 & $\begin{array}{c}\text { SS } 304 \\
141 \\
(8.1)\end{array}$ & $\begin{array}{c}\text { SS } 316 \\
149 \\
(2.3)\end{array}$ & $\begin{array}{c}\text { PVC } \\
203 \\
(13)\end{array}$ & $\begin{array}{c}\text { Control } \\
206 \\
(10)\end{array}$ & $\begin{array}{r}\text { PTFE } \\
214 \\
(1.5)\end{array}$ \\
\hline
\end{tabular}

\begin{tabular}{|c|c|c|c|c|c|c|}
\hline \multicolumn{3}{|c|}{ Flushes } & \multicolumn{4}{|c|}{ Well casing } \\
\hline \multicolumn{7}{|c|}{ Nickel (in bleed-off line, $n=3,0.72,{ }^{*} 0.40^{\dagger}$ ) } \\
\hline$(\mathrm{LSD}=4.09)$ & 5 & $\begin{array}{c}\text { PVC } \\
0.41 \\
(0.36)\end{array}$ & $\begin{array}{c}\text { Control } \\
0.44 \\
(0.20)\end{array}$ & $\begin{array}{c}\text { PTFE } \\
0.48 \\
(0.20)\end{array}$ & $\begin{array}{c}\text { SS } 316 \\
19.5 \\
(0.70)\end{array}$ & $\begin{array}{r}\text { SS } 304 \\
55.2 \\
(3.3)\end{array}$ \\
\hline$(\mathrm{LSD}=2.21)$ & 10 & $\begin{array}{c}\text { Control } \\
0.42 \\
(0.16)\end{array}$ & $\begin{array}{c}\text { PTFE } \\
0.42 \\
(0.16)\end{array}$ & $\begin{array}{c}\text { PVC } \\
0.48 \\
(0.32)\end{array}$ & $\begin{array}{c}\text { SS } 316 \\
20.5 \\
(0.21)\end{array}$ & $\begin{array}{r}\text { SS } 304 \\
40.2 \\
(1.8)\end{array}$ \\
\hline$(\mathrm{LSD}=3.10)$ & 15 & $\begin{array}{c}\text { PTFE } \\
0.24 \\
(0.18)\end{array}$ & $\begin{array}{c}\text { Control } \\
0.34 \\
(0.34)\end{array}$ & $\begin{array}{c}\text { PVC } \\
0.58 \\
(0.13)\end{array}$ & $\begin{array}{c}\text { SS } 316 \\
15.6 \\
(0.20)\end{array}$ & $\begin{array}{r}\text { SS } 304 \\
32.1 \\
(2.6)\end{array}$ \\
\hline
\end{tabular}




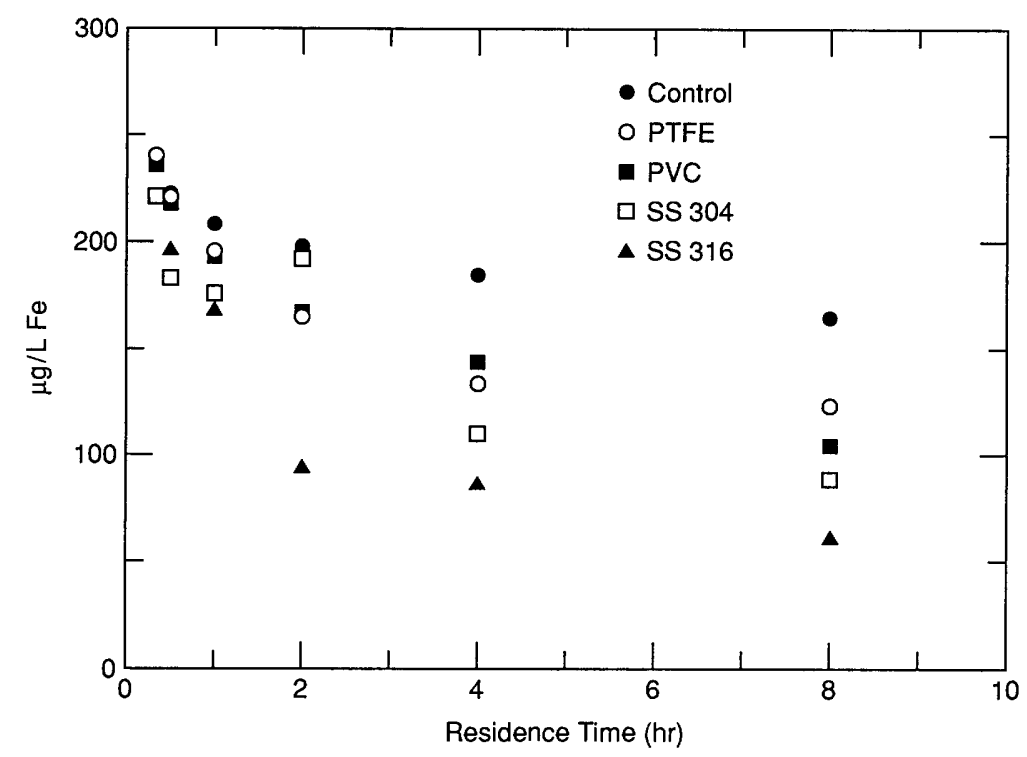

Figure 2. Total Fe concentration $(m g / L)$ in groundwater as a function of residence time.

\section{DISCUSSION}

These experiments realistically exposed well screens to the groundwater for periods consistent with compliance sampling, while maintaining major water quality parameters (Table 3). However, there may have been some analyte losses that were independent of the well screen materials (Table 4), as suggested by the low total $\mathrm{Fe}$ in the control compared to the average bleed-off line Fe concentration for tests having the longest residence time (8 hours). This analyte loss is consistent with the appearance in all of the chambers of small amounts of an orange colored precipitate, presumably "hydrated ferric oxid" $\left[\mathrm{Fe}_{2} \mathrm{O}_{3}-3 \mathrm{H}_{2} \mathrm{O}\right]$. This potential experimental artifact was most likely caused by the unplanned interruptions to continuous flow (Table 3), and exemplifies the care required to prevent shifts in chemical equilbria of groundwater.

When the polymeric materials are compared to the control, there were significant Fe losses from solution during tests with residence times of 2 hours and greater. A possible explanation for this additional loss of total Fe is that these screens displayed poor wetting characteristics, thus trapping air during the initial chamber filling, and providing a source of oxygen for the formation of $\mathrm{Fe}_{2} \mathrm{O}_{3}-3 \mathrm{H}_{2} \mathrm{O}$. The stainless steel screens did not retain air bubbles; however, it was visibly apparent after 2 weeks of exposure that these materials rapidly corroded. Before the second experiment was conducted ( 75 days after initial groundwater exposure), approximately 20 and $5 \%$ of the external surfaces of the SS 304 and
SS 316, respectively, were discolored. These sites of corrosion started with black or dark green centers rimmed by bands of orange, and were located either on welds or at points where the coiled screen attached to the vertical rods. This observation, along with the low dissolved oxygen state of the groundwater (Table 3), is consistent with the precipitation of ferrous hydroxide $\left[\mathrm{Fe}(\mathrm{OH})_{2}\right]$ by galvanic corrosion (Lloyd and Heathcote 1985), thus providing a mechanism for the loss of ferrous iron from solution. With time, the hydrated ferrous oxide slowly oxidized further to the hydrated ferric oxide.

Other than the decrease of total Fe (Fig. 2), increasing the length of exposure failed to produce any general trends. Our inability to observe trends correlating with residence time was confounded by the number of well volumes passing through the chambers prior to sampling, and by interruptions to continuous flow. Aqueous samples representative of shorter contact times (i.e., faster recharge) experienced the smallest number of chamber flushes (i.e., cleansing), while intermittent flow imposes uncertainty in the material exposure periods, since the exchange of five volumes through this type of system would not necessarily completely remove an influence caused by stagnation. The combination of these effects may explain why the elevated levels of $\mathrm{Cu}, \mathrm{Cr}$ and $\mathrm{Ni}$ were independent of residence time.

The experiment performed after the development of visible corrosion on the stainless well screens showed significant material effects for $\mathrm{Fe}, \mathrm{Cr}$ and $\mathrm{Ni}$, which persisted after 15 system flushes. Moreover, the magnitude of the influence was greater 
than for virgin, uncorroded materials. Comparing the average solution concentrations between the second experiment and those obtained during the 0.5hour residence time test for the first experiment shows increases of 10 times for the leaching of $\mathrm{Cr}$ and $\mathrm{Ni}$, and 2.5 times for the sorption of total $\mathrm{Fe}$. Most likely the amount of corrosion on the surface of the two stainless screens magnifies their influence on aqueous metal chemistry. Moreover, these results suggest that the extent of corrosion of stainless steel well screens with time might be inferred from increasing levels of $\mathrm{Ni}$ and $\mathrm{Cr}$ in groundwater samples.

The leaching of metals from of these two stainless steels has been observed under both anoxic and normal atmospheric conditions (Hewitt 1989a,b, 1991). Furthermore, with the development of iron oxides, new surfaces are generated that provide large and active exchange sites for the sorption of metals from solution. Although there is no strong evidence for this loss mechanism, it is a reasonable hypothesis to account for the decrease in $\mathrm{Cu}$ that we observed after day one, during the residence time study, and our failure to detect $\mathrm{Cu}$ above the MDL during the study conducted after surface corrosion developed.

Under these experimental conditions, $\mathrm{Cd}$ and $\mathrm{Pb}$ were not consistently found above their MDLs, and TCE showed no significant material effect, while $\mathrm{Cu}$ was either depleted from solution by cleansing (chamber flushing) or sorbed by surface-active Fe oxides. Thus, unlike in static laboratory experiments, we found no significant polymeric material influences under conditions that limited exposure to 8 hours or less and allowed for material cleansing. However, independent of the residence time, aqueous concentrations of $\mathrm{Cr}, \mathrm{Ni}$ and $\mathrm{Fe}$ in groundwater exposed to stainless steel casings continued to be significantly compromised. The extent of this influence depended highly on the corrosion state of the screen surface. Consistent with previous studies (Hewitt 1989a,b, 1991), stainless steel casings present the greatest challenge for obtaining representative metal concentrations in groundwater samples.

\section{CONCLUSION}

Material effects from common stainless steel well screen materials remain significant under dynamic conditions that are consistent with typical groundwater sampling protocols. The magnitude of influence appears directly correlated with how much corrosion there is on the stainless steel casings, and can reach concentration levels that would affect reg- ulatory compliance for both Ni and Cr. Only PVC and PTFE, which showed no material influences under dynamic sampling conditions (0.25- to 8-hour exposure) for $\mathrm{Cd}, \mathrm{Cr}, \mathrm{Cu}, \mathrm{Ni}, \mathrm{Pb}$ and TCE, should be recommended for constructing wells to monitor metals in groundwater.

\section{LITERATURE CITED}

Barcelona, M.J. and J.A. Helfrich (1986) Well construction and purging effects on ground-water samples. Environmental Science and Technology, 20(11): 1179_ 1184.

Dietz, E.A., Jr. and K.F. Singley (1979) Determination of chlorinated hydrocarbons in water by headspace gas chromatography. Analytical Chemistry, 51: 18091814.

Federal Register (1984) Definition and procedure for the determination of the method detection limit. Code of Federal Regulations, Part 136, Appendix B, October 26.

Federal Register (1975) Maximum allowable limits in drinking water. 40(51): 11990-11998.

Gillham, RW. and S.T. O'Hannesin (1988) Sorption of aromatic hydrocarbons by materials used in construction of ground-water sampling wells. In Ground Water and Vadose Monitoring (D.M. Neilsen and A.I. Johnson, Eds.). Philadelphia: American Society for Testing and Materials, ASTMSTP 1053, pp. 108-122. Hewitt, A.D. (1989a) Influence of well casing composition on trace metals in groundwater. USA Cold Regions Research and Engineering Laboratory, Special Report 89-32.

Hewitt, A.D. (1989b) Leaching of metal pollutants from four well casings used for groundwater monitoring. USA Cold Regions Research and Engineering Laboratory, Special Report 89-32.

Hewitt, A.D. (1992) Potential of common well casing materials to influence aqueous metal concentrations. Ground Water Monitoring Review, 12(2): 131-136.

Hewitt, A.D., P.H. Miyares, D.C. Leggett and T.F. Jenkins (1991) Comparison of headspace gas chromatography with EPA SW-846 method 8240 for determination of volatile organic compounds in soils. USA Cold Regions Research and Engineering Laboratory, Special Report 91-4.

Houghton, R.L. and M.E. Berger (1984) Effects of well casings composition on sampling method on apparent quality of groundwater. In Proceedings, The Fourth National Symposium and Exposition on Aquifer Restoration and Ground Water Monitoring, 23-25 May. Worthington, Ohio: National Water Well Association, pp. 203-213.

Lloyd J.W. and J.A. Heathcote (1985) Natural Inorgan- 
ic Hydrochemistry in Relation to Ground Water: An Introduction. Oxford: Clarendon Press.

Nielsen, D.M. (1988) Much ado about nothing: The monitoring well construction material controversy. Ground Water Monitoring Review, 8(1): 4-5.

Parker. LV., A.D. Hewitt and T.F. Jenkins (1990) Influence of casing materials on trace-level chemicals in well water. Ground Water Monitoring Review, 10(2): 146-156.

Reynolds, G.W. and R.W. Gillham (1986) Adsorp- tion of halogenated organic compounds by polymer materials commonly used in groundwater monitors. In Proceedings of the Second Canadian/American Conference on Hydrogeology, Banff, Alberta, Canada, June 25-29, 1985. Dublin, Ohio: National Water Well Association.

Reynolds, G.W., J.T. Hoff and RW. Gillham (1990) Sampling bias caused by materials used to monitor halocarbons in groundwater. Environmental Science and Technology, 24(1): 135-142. 


\section{APPENDIX A: EFFECT OF OXIDATION SITES ON METALS}

A third experiment not covered in the text of this report was conducted to determine the potential effect that oxidation sites had on metals that were introduced into the groundwater before entering the chamber system. Thus, during the third experiment, aqueous $\mathrm{Pb}^{2+}$ and $\mathrm{Cd}^{2+}$ were spiked into the groundwater stream via a syringe pump at a rate to create aqueous concentrations of approximately $28 \mathrm{mg} \mathrm{Pb} /$ $\mathrm{L}$ and $1.1 \mathrm{mg} \mathrm{Cd} / \mathrm{L}$. A coil of tygon tubing and new manifold were added to the system to ensure proper analyte mixing and to maintain a constant tubing length between the analyte introduction point and the chamber inlets. Samples were collected after 5, 6, $7,8,9$ and 10 chamber flushes for the third experiment, and the syringe pump was activated after the first and turned off after the third sample collections (first $=5$, third $=7$ chamber flushes respectively). For this experiment, as with the second, the chamber flushing rate was 0.5 hour.

Although $\mathrm{Cu}$ was found to be significantly influence by well screen materials, no distinct pattern developed, nor were the concentrations much above the MDL. As in the second experiment, both SS 316 and SS 304 significantly leached $\mathrm{Cr}$ and $\mathrm{Ni}$ and sorbed $\mathrm{Fe}$. The spiking of $\mathrm{Pb}$ and $\mathrm{Cd}$ into the groundwater resulted in statistically significant effects for all of the materials tested. Preceding analyte introduction, both polymeric screens sorbed $\mathrm{Pb}$, then PTFE showed an apparent memory effect, followed by yet another display of sorption by both PVC and PTFE. For Cd, both polymeric screens showed an initial memory effect, followed by a sorption effect. The stainless screens showed consistent sorption trends that were usually significantly greater than the polymeric casings. 
Table A1. Summary of statistical analyses for average analyte concentrations $(\mu \mathrm{g} / \mathrm{L})$ during spiked flushing study of corroded stainl ess steel screens. Materials with common underlining are not different at the $95 \%$ confidence level as determined by the least significant difference (LSD) test.

Flushes

Well casing

\section{Copper (in bleed-off line, $n=6,1.12, * 0.37^{+}$)}

5 PTFE SS 316 PVC Control SS 304 $\begin{array}{lllcr}1.50 & 1.63 & 1.70 & 1.77 & 2.10^{*}\end{array}$ $\begin{array}{lllll}(0.26) & (0.06) & (0.17) & (0.06) & (0.10)^{\dagger}\end{array}$

\begin{tabular}{ccccccc}
\cline { 3 - 5 }$(\mathrm{LSD}=0.20)$ & 6 & PTFE & SS 316 & SS 304 & PVC & Control \\
& & 1.27 & 1.27 & 1.37 & 1.57 & 1.57
\end{tabular}

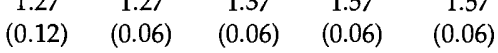
\begin{tabular}{llll}
$(0.12) \quad(0.06)$ & $(0.06)$ & $(0.06)$ & $(0.06)$ \\
\hline
\end{tabular}

\begin{tabular}{ccccccc}
\cline { 3 - 6 }$(\mathrm{LSD}=0.18)$ & 7 & PTFE & SS 316 & Control & PVC & SS 304 \\
& & 0.77 & 0.90 & 0.97 & 1.03 & 1.07
\end{tabular}
$\begin{array}{ccccc}0.77 & 0.90 & 0.97 & 1.03 & 1.07 \\ (0.06) & (0.0) & (0.12) & (0.06) & (0.06)\end{array}$

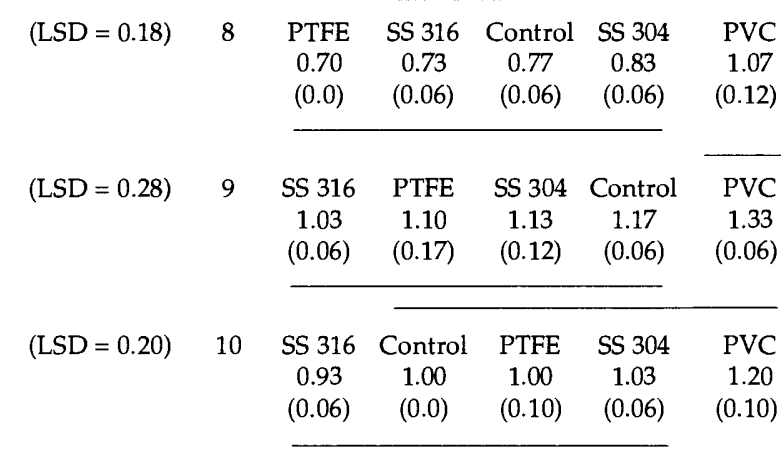

* average

t standard deviation
Well casing

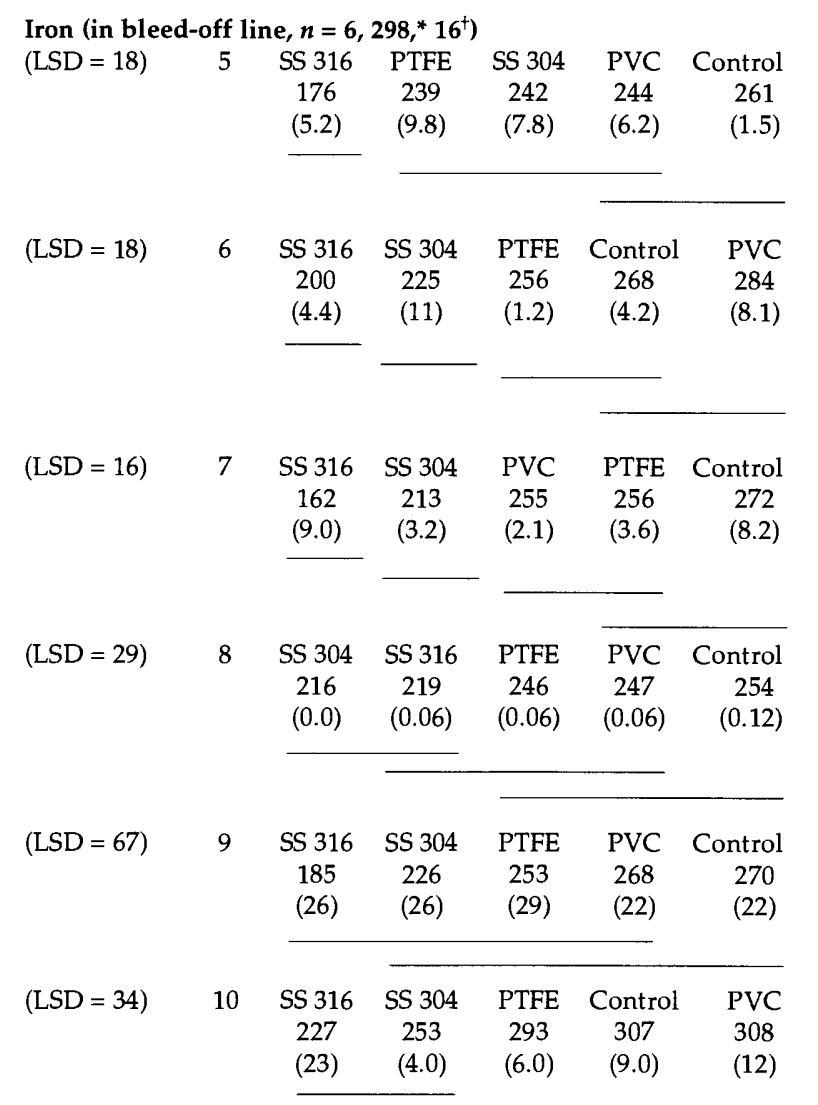

\begin{tabular}{|c|c|c|c|c|c|c|}
\hline \multicolumn{3}{|c|}{ Flushes } & \multicolumn{3}{|c|}{ Well casing } & \\
\hline \multicolumn{7}{|c|}{ Nickel (in bleed-off line, $n=6,0.47,0.37^{+}$) } \\
\hline$(\mathrm{LSD}=6.55)$ & 5 & $\begin{array}{c}\text { Control } \\
0.37 \\
(0.29)\end{array}$ & $\begin{array}{c}\text { PVC } \\
0.40 \\
(0.26)\end{array}$ & $\begin{array}{c}\text { PTFE } \\
0.60 \\
(0.35)\end{array}$ & $\begin{array}{c}\text { SS } 304 \\
91.8 \\
(4.04)\end{array}$ & $\begin{array}{c}\text { SS } 316 \\
97.0 \\
(3.62)\end{array}$ \\
\hline$(\mathrm{LSD}=1.77)$ & 6 & $\begin{array}{c}\text { PVC } \\
0.20 \\
(0.10)\end{array}$ & $\begin{array}{c}\text { Control } \\
0.33 \\
(0.23)\end{array}$ & $\begin{array}{c}\text { PTFE } \\
0.53 \\
(0.21)\end{array}$ & $\begin{array}{c}\text { SS } 316 \\
32.3 \\
(1.40)\end{array}$ & $\begin{array}{r}\text { SS } 304 \\
40.6 \\
(0.32)\end{array}$ \\
\hline$(\mathrm{LSD}=4.75)$ & 7 & $\begin{array}{c}\text { PVC } \\
0.33 \\
(0.21)\end{array}$ & $\begin{array}{c}\text { PTFE } \\
0.50 \\
(0.10)\end{array}$ & $\begin{array}{c}\text { Control } \\
0.53 \\
(0.25)\end{array}$ & $\begin{array}{c}\text { SS } 304 \\
40.1 \\
(2.17)\end{array}$ & $\begin{array}{c}\text { SS } 316 \\
66.8 \\
(3.29)\end{array}$ \\
\hline$(\mathrm{LSD}=4.89)$ & 8 & $\begin{array}{c}\text { Control } \\
0.17 \\
(0.06)\end{array}$ & $\begin{array}{c}\text { PTFE } \\
0.23 \\
(0.15)\end{array}$ & $\begin{array}{c}\text { PVC } \\
0.33 \\
(0.06)\end{array}$ & $\begin{array}{c}\text { SS } 304 \\
23.3 \\
(2.97)\end{array}$ & $\begin{array}{r}\text { SS } 316 \\
32.7 \\
(2.77)\end{array}$ \\
\hline$(\mathrm{LSD}=1.85)$ & 9 & $\begin{array}{c}\text { Control } \\
0.50 \\
(0.17)\end{array}$ & $\begin{array}{c}\text { PTFE } \\
0.60 \\
(0.35)\end{array}$ & $\begin{array}{c}\text { PVC } \\
0.67 \\
(0.31)\end{array}$ & $\begin{array}{c}\text { SS } 304 \\
26.0 \\
(0.06)\end{array}$ & $\begin{array}{c}\text { SS } 316 \\
60.1 \\
(1.46)\end{array}$ \\
\hline$(\mathrm{LSD}=10.1)$ & 10 & $\begin{array}{c}\text { PVC } \\
0.53 \\
(0.12)\end{array}$ & $\begin{array}{c}\text { PTFE } \\
0.60 \\
(0.0)\end{array}$ & $\begin{array}{c}\text { Control } \\
0.70 \\
(0.10)\end{array}$ & $\begin{array}{c}\text { SS } 304 \\
20.6 \\
(0.70)\end{array}$ & $\begin{array}{c}\text { SS } 316 \\
32.8 \\
(8.36)\end{array}$ \\
\hline
\end{tabular}


Table A1 (cont'd).

Flushes

Well casing

Chromium (in bleed-off line, $n=6,0.05 * 0.05^{\dagger}$ )

$(\mathrm{LSD}=0.74) \quad 5 \quad$ PVC Control PTFE SS $316 \quad$ SS 304 $\begin{array}{lllll}0.07 & 0.10 & 0.23 & 4.67 & 9.93\end{array}$ \begin{tabular}{ccccc}
0.07 & 0.10 & 0.23 & 4.67 & 9.93 \\
$(0.06)$ & $(0.10)$ & $(0.15)$ & $(0.06)$ & $(0.59)$ \\
\hline
\end{tabular}

$-(0.06)+(0.10)+(0)$

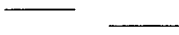

$(\mathrm{LSD}=0.33) \quad 6 \quad$ PVC $\quad$ Control PTFE $\quad$ SS $316 \quad$ SS 304 $\begin{array}{lllll}0.07 & 0.13 & 0.23 & 0.87 & 1.87\end{array}$ $\begin{array}{lllll}(0.06) & (0.06) & (0.25) & (0.06) & (0.06)\end{array}$

$\longrightarrow$

\begin{tabular}{|c|c|c|c|c|c|}
\hline$(\mathrm{LSD}=0.63)$ & 7 & $\begin{array}{c}\text { PVC } \\
0.03 \\
(0.06)\end{array}$ & $\begin{array}{c}\text { PTFE } \\
0.03 \\
(0.06)\end{array}$ & $\begin{array}{c}\text { Control } \\
0.07 \\
(0.12)\end{array}$ & $\begin{array}{c}\text { SS } 304 \\
1.90 \\
(0.44)\end{array}$ \\
\hline$(\mathrm{LSD}=1.04)$ & 8 & $\begin{array}{c}\text { Control } \\
0.07 \\
(0.06)\end{array}$ & $\begin{array}{c}\text { PVC } \\
0.13 \\
(0.06)\end{array}$ & $\begin{array}{c}\text { PTFE } \\
0.23 \\
(0.15)\end{array}$ & $\begin{array}{c}\text { SS 304 } \\
0.67 \\
(0.12)\end{array}$ \\
\hline
\end{tabular}

$(\mathrm{LSD}=0.35) \quad 9 \quad$ Control PVC $\quad$ PTFE SS $304 \quad$ SS 316 $\begin{array}{lllll}0.03 & 0.03 & 0.13 & 0.53 & 2.50\end{array}$ $\begin{array}{lllll}(0.06) & (0.06) & (0.23) & (0.12) & (0.10)\end{array}$

$\longrightarrow-$

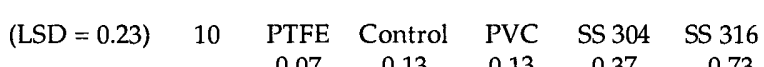
\begin{tabular}{ccccc}
0.07 & 0.13 & 0.13 & 0.37 & 0.73 \\
$(0.06)$ & $(0.06)$ & $(0.06)$ & $(0.06)$ & $(0.15)$ \\
\hline
\end{tabular} $\begin{array}{llll}(0.06) \quad(0.06) & (0.06) & (0.06) \quad(0.15)\end{array}$
Flushes

Well casing

Cadmium (in bleed-off line $\left.n=6,0.01 * 0.01^{\dagger}\right)$

5 PVC SS 316 SS 304 Control PTFE

PVC SS 316 SS 304 Control PTFE

$\begin{array}{ccccc}0.01 & 0.01 & 0.02 & 0.02 & 0.03 \\ (0.0) & (0.01) & (0.01) & (0.02) & (0.01)\end{array}$

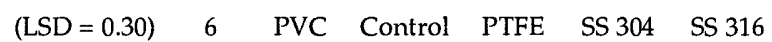

$\begin{array}{lllll}0.41 & 0.41 & 0.45 & 0.45 & 0.71\end{array}$

$\begin{array}{lllll}(0.13) & (0.06) & (0.08) & (0.07) & (0.17)\end{array}$

$\begin{array}{lllllll}(\mathrm{LSD}=0.06) & 7 & \text { SS } 304 & \text { SS } 316 & \text { PTFE } & \text { Control } & \text { PVC }\end{array}$

$\begin{array}{lllll}0.67 & 1.05 & 1.45 & 1.47 & 1.52\end{array}$

$\begin{array}{llll}(0.03) & (0.02) \quad(0.02) & (0.03) \quad(0.02)\end{array}$

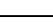

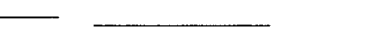

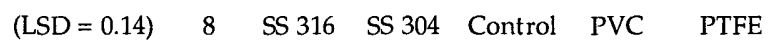

$\begin{array}{lllll}0.43 & 0.46 & 0.72 & 1.10 & 1.16\end{array}$

$\begin{array}{ccccc}0.43 & 0.46 & 0.72 & 1.10 & 1.16 \\ (0.05) & (0.03) & (0.15) & (0.08) & (0.06)\end{array}$

$+$

$(\mathrm{LSD}=0.10) \quad 9 \quad$ SS $316 \quad$ SS $304 \quad$ PTFE $\quad$ PVC Control

$\begin{array}{ccccc}0.19 & 0.28 & 0.29 & 0.34 & 0.50 \\ (0.03) & (0.01) & (0.03) & (0.02) & (0.07)\end{array}$

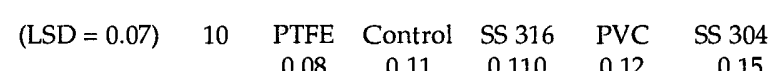

\begin{tabular}{ccccc}
0.08 & 0.11 & 0.110 & 0.12 & 0.15 \\
$(0.01)$ & $(0.03)$ & $(0.02)$ & $(0.04)$ & $(0.02)$ \\
\hline
\end{tabular}
Flushes

Well casing

\section{(in bleed-off line, $\left.n=6,0.05 * 0.05^{+}\right)$}

$\begin{array}{lllll} & \text { Control SS } 316 & \text { PTFE PVC SS } 304\end{array}$ $\begin{array}{lllll}0.03 & 0.03 & 0.13 & 0.17 & 0.17\end{array}$ \begin{tabular}{ccccc}
0.03 & 0.03 & 0.13 & 0.17 & 0.17 \\
$(0.06)$ & $(0.06)$ & $(0.12)$ & $(0.06)$ & $(0.12)$ \\
\hline
\end{tabular}

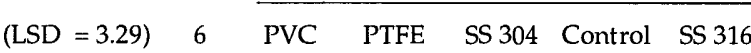

$\begin{array}{lllll}3.13 & 4.73 & 4.87 & 5.37 & 8.47\end{array}$

$\begin{array}{lllll}(0.13) & (0.99) & (0.95) & (0.91) & (1.90)\end{array}$

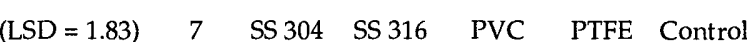
$\begin{array}{llllr}5.80 & 10.4 & 13.2 & 16.5 & 24.2\end{array}$ $\begin{array}{lllll}(0.30) & (0.15) & (0.02) & (0.79) & (1.11)\end{array}$

$(\mathrm{LSD}=2.11) \quad 8 \quad$ SS $316 \quad$ SS $304 \quad$ PVC $\quad$ Control PTFE $\begin{array}{lcccc}1.83 & 2.70 & 8.97 & 9.33 & 14.3\end{array}$

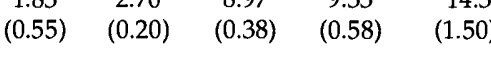

$\longrightarrow$

$(\mathrm{LSD}=1.64) \quad 9 \quad$ SS $316 \quad$ SS $304 \quad$ PTFE $\quad$ PVC Control $\begin{array}{lllll}0.73 & 1.40 & 2.70 & 2.77 & 7.23\end{array}$ $\begin{array}{lllll}(0.15) & (0.10) & (0.26) & (0.15) & (1.32)\end{array}$

$(\mathrm{LSD}=1.83) \quad 10 \quad$ SS $316 \quad$ SS $304 \quad$ PTFE $\quad$ PVC Control $\begin{array}{lllll}0.33 & 0.43 & 087 & 1.43 & 1.47\end{array}$ $\begin{array}{lllll}(0.32) & (0.23) & (0.12) & (0.31) & (0.38)\end{array}$

† standard deviation 
Public reporting burden for this collection of information is estimated to average 1 hour per response, including the time for reviewing instructions, searching existing data sources, gathering and maintaining the data needed, and completing and reviewing the collection of information. Send comments regarding this burden estimate or any other aspect of this collection of information, including suggestion for reducing this burden, to Washington Headquarters Services, Directorate for Information Operations and Reports, 1215 Jefferson Davis Highway, Suite 1204, Arlington, VA 22202-4302, and to the Office of Management and Budget, Paperwork Reduction Project (0704-0188), Washington, DC 20503.

\begin{tabular}{|l|c|l|l}
\hline 1. AGENCY USE ONLY (Leave blank) & $\begin{array}{c}\text { 2. REPORT DATE } \\
\text { July } 1993\end{array}$ & 3. REPORT TYPE AND DATES COVERED \\
\hline
\end{tabular}

4. TITLE AND SUBTITLE

A Dynamic Study of Common Well Screen Materials

6. AUTHORS

Alan D. Hewitt

7. PERFORMING ORGANIZATION NAME(S) AND ADDRESS(ES)

8. PERFORMING ORGANIZATION REPORT NUMBER

U.S. Army Cold Regions Research and Engineering Laboratory

72 Lyme Road

CRREL Report 93-7

Hanover, New Hampshire 03755-1290

9. SPONSORING/MONITORING AGENCY NAME(S) AND ADDRESS(ES)

10. SPONSORING/MONITORING

U.S. Army Environmental Center

Aberdeen Proving Ground, Maryland AGENCY REPORT NUMBER

CETHA-TS-CR-93049

11. SUPPLEMENTARY NOTES

12a. DISTRIBUTION/AVAILABILITY STATEMENT

12b. DISTRIBUTION CODE

Approved for public release; distribution is unlimited.

Available from NTIS, Springfield, Virginia 22161.

13. ABSTRACT (Maximum 200 words)

This report describes a dynamic study of the effects of well screen materials on the chemistry of groundwater during contact periods that are consistent with compliance sampling. Tests were done by passing TCE-contaminated aquifer water through monitoring well screens held in a special chamber, without significant changes in major water quality parameters. The results indicate that polymeric materials (i.e., rigid polyvinyl chloride and polytetrafluoroethylene) do not influence aqueous metal and TCE concentrations, while stainless steel casings significantly influence aqueous concentrations of $\mathrm{Cr}$, $\mathrm{Ni}$ and $\mathrm{Fe}$, especially after developing surface corrosions.

\begin{tabular}{|lll}
\hline 14. SUBJECT TERMS & & \\
Groundwater & PTFE & Stainless steel \\
Groundwater sampling & PVC & Well casing
\end{tabular}

17. SECURITY CLASSIFICATION OF REPORT

UNCLASSIFIED

\begin{tabular}{|c|c|}
\hline $\begin{array}{c}\text { 18. SECURITY CLASSIFICATION } \\
\text { OF THIS PAGE } \\
\text { UNCLASSIFIED }\end{array}$ & $\begin{array}{c}\text { 19. SECURITY CLASSIFICATION } \\
\text { OF ABSTRACT } \\
\text { UNCLASSIFIED }\end{array}$ \\
\hline
\end{tabular}

UNCLASSIFIED

\begin{tabular}{|l|l|} 
& \begin{tabular}{c} 
15. NUMBER OF PAGES \\
\cline { 2 - 3 }
\end{tabular} \\
\hline $\begin{array}{l}\text { 19. PRICE CODE } \\
\text { OF ABSTRACT } \\
\text { UNCLASSSIFIED }\end{array}$ & 20. LIMITATION OF ABSTRACT \\
\hline
\end{tabular}

Standard Form 298 (Rev. 2-89) Prescribed by ANSI Std. Z39-18 298-102 